\title{
Brexit in the Workplace
}

\section{Chapter 9-A psychology of survival by Ashley Weinberg}

\section{WHO DARES WINS?}

The need for a handle on events and ultimately a sense of control remains paramount for organisations and employees. This is even more relevant given the advent of Coronavirus than when Brexit began. As discussed in the opening chapter, having a perception of agency over one's future is a key weapon in combating uncertainty - it underpins our well-being. Trust in others took a proverbial battering as far as UK Brexit politics is concerned - whether among voters or major players. Theresa May was replaced by Boris Johnson as Prime Minister and thereafter the issue of distrust was further exemplified in unprecedented and bizarre events in Parliament. First as the Prime Minister stood to give his maiden speech in the role, one of his own MPs rose and crossed the floor of the House of Commons. This simple act carried huge political significance. Not only did it signal the MP's desire to leave the Conservative Party, personally challenging the authority of the Prime Minister, but it actually changed parliamentary arithmetic. Without this MP's support, Boris Johnson no longer had a majority to govern.

What followed broke with parliamentary precedent in many ways and provoked a constitutional crisis. The idea that Brexit was achievable by negotiation with the EU and that a Brexit Deal might be approved by Parliament seemed the farthest of possibilities. In the House of Commons, any sense of trepidation quickly switched to alarm. The Prime Minister announced that he was going to prorogue Parliament for the longest period since the Second World War. Boris Johnson claimed it was to permit a new session of Parliament and allow his Government to introduce new legislation. However, in effect it would also end the potential for any parliamentary debate of Brexit arrangements until mid-October and mean a leap towards the UK leaving the EU without a deal at the end of the same month. The explosion of emotion from MPs inside his party and the Opposition was immediate. Politicians who were his political allies and enemies had already spoken of distrusting Boris Johnson because of his seemingly unbridled political ambition. To them and many observers, suspending Parliament represented a retrograde step towards a default position of the UK leaving the EU on 31 October without a deal. This Brexit strategy had ramifications for workplaces as well as the rest of the UK.

This closing chapter brings up to date the Brexit scenario at the time of the UK leaving the $\mathrm{EU}$ and seeks to draw out the key psychological issues for workplaces in the coming months and years, as new trade deals between the UK and business partners across Europe and further afield are negotiated.

\section{DEMOCRACY UNDER THREAT?}

What galvanised people's emotions and actions was the perception that the Prime Minister was dismissing Parliament - the elected voice of the people - and thereby ignoring democratic rule. At best, he claimed to be advancing government in a new session of Parliament to discuss other pressing domestic matters including crime and health, while at 
worst he was ushering in Brexit by the back door and without due process. Political hearts and minds went into overdrive as tens of thousands took to the streets in protest in cities across the UK, 1.4 million signed a petition against the suspension of Parliament, MPs staged a sit-in singing songs of protest on the day of prorogation and legal petitions were lodged at courts in London and Edinburgh to reverse the suspension of Parliament.

However, before the Prime Minister had his way, MPs from all sides of the House of Commons cooperated to take over the parliamentary schedule and propose their own Bill to avoid what many considered the worst case scenario of a No Deal Brexit. Proposed by former Labour minister Hilary Benn, what became known as the Benn Act - referred to disparagingly by Boris Johnson as the 'Surrender Bill' - demanded that the Prime Minister would have to request a delay to the UK exit beyond 31 October in the event of no agreement on a Brexit Deal. The Prime Minister countered this defiance by withdrawing the party whip from Conservative MPs who had supported Hilary Benn's proposal and effectively ejected them from the party. These included the longest serving MPs Kenneth Clark and grandson of Sir Winston Churchill Sir Nicholas Soames.

Defeat for the Prime Minister in the UK Supreme Court followed, ruling he had acted unlawfully in suspending Parliament. There were claims he had misled the Queen in advising her it was appropriate to prorogue Parliament. The Speaker of the House of Commons immediately recalled MPs and the tone of the parliamentary workplace changed. There was a withdrawal of goodwill by MPs prompted by these events and they rejected the Prime Minister's request to suspend debates for the Conservative Party conference. The personality of the new Prime Minister appeared to prime him to use a more combative approach than his predecessor. While Theresa May was deserted by her parliamentary colleagues for failures to listen and to engage across parties, Boris Johnson actively sought to defeat those he perceived as his enemies, even if this lost him a working parliamentary majority. The Conservative Party conference went ahead, with MPs travelling by train between London and Manchester. There was no alteration in the Prime Minister's ebullience. His closing speech to the party faithful was a performance with which they were already familiar. They had gathered in Manchester to discuss their party's way forward, including the Prime Minister's recent ejection of dissenting MPs. There was uncertainty regarding how Brexit might yet unfold - if at all - as well as anxieties for the Government of losing power, as a General Election seemed inevitable. The next three months were to decide the future of Brexit and highlight key issues for the UK, including the parliamentary organisation described by Richard Kwiatkowski in Chapter 7.

Seeking to capitalise on what is traditionally an opportunity to lift the mood of political allies, Boris Johnson released his version of a Brexit Deal proposal to conference cheers, including from those whose opposition had ended the career of his predecessor. The political dice seemed poised to fall and risked overturning him too. The European Union no longer dismissed the idea of revisiting the deal they had negotiated with Mrs May - which was a shift in their rhetoric - but appeared as scathing as the UK opposition parties on first viewing detail of his proposals. With one month to go before the (then) deadline for leaving 
the EU, pressure mounted on all sides to either 'Get Brexit done', as Mr Johnson and the Conservative Party conference slogan proclaimed, or to move for a delay.

The impact on UK work organisations continued to become manifest. The Lancet had previously published its evaluation of the impact of Brexit on the National Health Service and concluded, 'All forms of Brexit are bad for health, but some are worse than others' (Fahy et al., 2019, p. 949), with 'No Deal' projected to represent the worst outcome. Even at the point of leaving, $40 \%$ of SMEs responding to a YouGov (2020) survey claimed they were not yet prepared. In the autumn of 2019, government departments were stockpiling medicines in a way which had only been predicted earlier in the year. Small and mediumsized enterprises evidenced outlay and upheaval to offset anticipated shortages in their physical and human resources. One high street supplier spent $£ 12$ million to 'future proof' itself in just six months and saw the departure of its largely Polish workforce, whose efforts had helped the firm reach its zenith. As Ivett Racz's chapter has shown (Chapter 3 ), dilemmas facing Hungarian workers in the UK were no different. The Polish ambassador Arkady Rzegocki wrote to 900000 of his compatriots living in the UK in mid-September 2019 encouraging them to 'seriously consider' returning to Poland. This introduced a new dynamic into the equation. His motivation may have been driven by concerns that only $27 \%$ of Poles had applied to the settlement scheme which would allow them to remain without further complications, or perhaps by enthusiasm for the steady expansion of the economy back in Poland. Either way, Ivett's consideration of facilitators and barriers to employment shows that whether intended by Brexit supporters or not, there had been a negative impact on migrants who had moved to the UK whose efforts had helped to boost UK productivity. The role of Brexit is a poignant reminder of how politics affects individual lives in ways which should have been anticipated. At a fringe meeting organised by the British Psychological Society during the Conservative Party Conference, attended by political candidates, policy advocates and lifelong party supporters, there were calls to raise awareness of the impact of government actions on others. This is seen as increasingly imperative for those devising government policies, regardless of political affiliation, as the cross-party partnership for compassion in UK politics has been keen to demonstrate (Compassion in Politics, n.d.).

The major sticking point for reaching a deal throughout the process had been the UK border with the EU in Northern Ireland. Chapter 2 by Richard Plenty and Terri Morrissey gives an insight into the psychological impact of impending Brexit on experiences of uncertainty, the political handling of risk and the implications for resilience. Their account is written from the perspective of a business operating across Ireland where the equation had not only featured the prospect of a customs border, but also the need to remain agile to the possibilities most importantly remaining mindful of the impact of Brexit arrangements on the peace invoked by the Good Friday Agreement (which incidentally had itself been ratified by a referendum in 1998). Viewed through the lens of peace or its alternatives, Terri and Richard's emphasis on resilience is poignant. The people of Northern Ireland have endured not only open and armed conflict during the 'Troubles', but the emotional aftermath, mixed with relief and a natural desire to see justice achieved. The role of reconciliation within the peacetime healing process cannot be underestimated, but the ties of identity are as strong 
as ever and this itself brought a challenging undertone to politics in Northern Ireland during Brexit. The suspension of the self-governing body at Stormont for other reasons further heightened tensions where political communities had previously been sharing power. The role of the Democratic Unionist Party in supporting the UK Government led by Theresa May had become vital for her successor in securing parliamentary support for his deal too.

\section{BORIS OR BUST?}

The new Prime Minister forged ahead, believing that although he had not been elected, he already had a mandate from the UK people to be in office. His guiding principle was 'Get Brexit done!' Indeed, the number of times Boris Johnson used this phrase is hard to estimate but it appeared to feature in his every speech, interview and public engagement in the run-up to the 2019 General Election.

Meanwhile at 2 am on 17 October 2019, the UK and EU negotiators had agreed a draft deal which could be put before their respective parliaments. The key change from the deal agreed previously with Theresa May's Government related to customs arrangements for goods passing between the UK and EU. A hard border was replaced by a customs border 'in the Irish sea' and the controversial 'backstop' arrangement was dropped. For the first time since 1982, Parliament was convened to sit on a Saturday to debate the deal. It was the last available opportunity for the Prime Minister to avoid having to ask for an extension to the 31 October Leave deadline. The passing of the Benn Act meant that Parliament rather than the Government could prevent Boris Johnson taking the UK out of the EU without a deal. The politics reached fever pitch.

The Saturday sitting took place in a city where it was estimated up to one million took to the streets to protest their opposition against leaving the EU. Meanwhile in Parliament, Conservative MP Oliver Letwin proposed that a 'meaningful' vote on the newly drafted UKEU deal should wait until the relevant legislation had passed through Parliament. In other words the UK should not leave the EU on 31 October. This raised the stakes for the Prime Minister who had said he would rather 'die in a ditch' than apply for another extension to the leaving date. The Benn Act obliged him to go back on his dire prediction and simply write the request to the EU - which he did apparently without signing it! Undeterred, the Prime Minister took the unusual step of proposing the dissolution of Parliament in order to trigger a General Election. Three times he proposed it and each time he was defeated by the majority of MPs. Parliamentary stalemate was eventually broken on 29 October when the Leader of the Opposition, Jeremy Corbyn, agreed to call a General Election after the EU had approved an extension to the 31 January for the UK to leave the EU. The decision to stay or go passed again to the UK people.

Boris Johnson promoted his 'oven ready' deal and sought to appeal to the impatience palpable in the country that the whole Brexit process had dragged on too long. By presenting a 'can do' approach to voters - even though it lacked the backing of Parliament before the General Election of December 2019 - the Prime Minister was able to tug at public desire for an end to the matter, 'Do or die!' Boris Johnson found it easier to encourage people to support something which had been shown to have demonstrable 
support than an alternative. It seemed to fit well with the Game Theory approach outlined in our opening chapter as it appealed to those who felt the democratic decision had been taken in the Referendum - for good or ill - and those voting Leave remained angry at suggestions, which some saw as undermining their judgement, that they were ill-informed. Furthermore, by casting any alternative as prolonging the wait ('dither and delay' as he termed it), the Prime Minister sought to destabilise support for renegotiation (favoured by Labour in order to re-run the Referendum) or indeed reversing the Referendum decision without a further vote (favoured by the Liberal Democrats). In the straightforward terms of the age-old political analogy, 'jam today' seemed an approach which was to triumph over the promise of 'jam tomorrow' or 'jam yesterday'. Harking back to the Conservation of Resources approach outlined in the opening chapter of this book, this appeared arguably to remove the greater sense of threat that many had felt about Brexit - to democracy itself. Here was someone promising to deliver what a majority had voted for and if this served democracy outside Parliament rather than within it, then so be it.

\section{FOR WHOM THE BELL TOLLS}

When voting ended on 12 December and the results of the exit poll for the General Election were announced at the stroke of $10 \mathrm{pm}$, the mood of the country changed once more. Trusting the methods of renowned psephologist Sir John Curtice, who had predicted a majority for Boris Johnson's Conservative Government, the nation finally saw a definite outcome of the Brexit debate which the following hours confirmed. The UK would leave the European Union.

Naturally emotions were expressed by those on both sides of the Leave-Remain debate, emotions which had characterised three and a half years of domestic and European Union politics and the tone of political discourse in homes and communities across the UK: relief or even joy on one side; surprise, disappointment and a level of acceptance on the other. The tensions which had riven media pronouncements, parliamentary process and public outcry appeared ready to dissipate. The Prime Minister acknowledged that areas of the countryparticularly the North and Midlands of England and parts of South Wales - which previously would not have voted for the Conservative Party had 'lent' him their support to 'get Brexit done'. He announced rather dramatically and perhaps optimistically too, 'Let the healing begin'. This implied some recognition of the conflict which had become all-consuming according to UK media and a topic only second to discussing the weather. At the time, Brexit appeared the far more important topic and any sense people might 'get over it' appeared short-sighted.

Electoral success for the Conservative Government indicated broad support for their approach to Brexit as the other social and domestic policies they offered were not starkly different from those previously included in their manifesto and traditionally rejected by Labour-voting areas. Meanwhile it appeared that age had become the important electoral turning point. In the EU Referendum, almost two-thirds of over-65s and a similar majority of over-50s voted for Leave, compared to almost three-quarters of 18-25-year-olds and a smaller majority of 25-49-year-olds supporting Remain (YouGov, 2016). In addition, interviews with over 40000 voters following the 2019 General Election revealed that $57 \%$ of 
those aged 60-69 supported the Conservatives (67\% among those over 70 ), compared to $21 \%$ of $18-25$-year-olds and $23-41 \%$ of those aged $25-49$ (YouGov, 2019). Naturally the turnout at elections means that around $30 \%$ of all potential voters do not take part, but based on those who did, it appeared that the majority of those of working age were against Brexit. In other words, the consequences of Brexit were more likely to be borne by those who had not supported it.

It remains to be seen whether the decision of voters to stick with the 2016 Referendum was linked to a need for consistency or instead attraction to what some saw as a 'strong' leadership style in turbulent times or indeed both. However, an illustration of a less than compromising approach to the workplace came with the prompt post-election announcement of the Government's new Brexit strategy. The Withdrawal Bill put before Parliament removed assurances given by Theresa May when she was Prime Minister that workers' rights would be safeguarded, by allowing judges in the UK's lower courts to overturn rulings of the European Courts of Justice (Personnel Today, 2019). This publicised U-turn meant uncertainty over whether the UK would in future match EU standards on employee rights. Chapter 5 by Christian van Stolk has considered the impact of such ongoing insecurity on the workforce. Indeed, fear of moving away from EU regulations had already triggered a warning letter from leaders of motor manufacturing, chemical, food and drink and pharmaceutical industries that widening the gap would pose, 'a serious risk to [...] competitiveness [...] [which] will result in huge new costs and disruption to UK firms' (Financial Times, 2019). As Chapter 4 by Imad Moosa highlights, such business concerns were not isolated or without foundation in established principles of economic forecasting. Indeed he cites lack of regulation as one predicted outcome of Brexit. The prolonging of uncertainty seemed inevitable as there were calls for more time than originally set aside to negotiate the necessary trade deals in 2020. Whatever these discussions hold, difficulties for employees could arise following UK-EU separation if the UK Government takes a negative view of what it may view as regulatory strictures. An economic downturn, as predicted earlier, would be likely to amplify such effects.

\section{WHAT HAPPENS NOW? A PSYCHOLOGY OF SURVIVAL}

The key themes arising from each chapter of this book highlight considerations for change scenarios such as Brexit. These are particularly important where political change - or indeed upheaval - bring about economic shifts in policy and practice and will doubtless be relevant in tackling wider environmental challenges we face. Each of the contributors has taken a different perspective which taps into Brexit's 'wicked' problems, to borrow the phrase favoured by some policy makers. By considering these together, it is possible to identify factors which shape a way forward.

Taking time to understand that organisations are made up of humans may sound trite, but the well-being factor permeates not only successful operation of organisations but also of governments too. The Brexit process has been infused with the spectre of threat for communities frustrated at not having a say - whether UK or EU citizens - for supporters or opponents of the EU referendum result, for Northern Ireland where deep conflict has characterised the recent past and for MPs in Parliament - where tragedy struck during the 
Brexit process with the murder of Jo Cox and where a number of politicians gave up careers after facing threats and abuse. Yet in the 2018 UK Government Green Paper 'Building our Industrial Strategy', well-being as a reflection of psychological and physical health was not featured, despite its recognised role in determining behaviour and influencing personal and wider financial costs. There was some attempt to rectify this omission with subsequent insertion of references to employee well-being in relation to the Taylor Report on modern working methods (Department of Business, Energy and Industrial Strategy, 2017). However, the concept of how best to safeguard the well-being of the nation - and of the workforce in particular - in undertaking Brexit was largely ignored. This is a mistake which organisations can attempt to rectify and cannot afford to ignore as the details of trade arrangements and workplace futures unfold. The closing section of this chapter and the book addresses such key psychological issues.

\section{A CASE FOR COMPASSION AND GOOD SENSE}

It is not surprising that the Brexit process has seen the full range of human emotions. As our opening chapter has charted, the impact of these should not be underestimated and workplaces can benefit from identifying and understanding them. Emotions underpin wellbeing and research shows that maintaining the well-being of employees is vital for a range of individual and organisational outcomes, for example even in predicting patient outcomes (Boorman, 2009). Although businesses experienced intense pressures, there is clearly a return on investment of resources in creating psychologically healthier and progressive approaches to work (Edmans, 2008).

Efforts to promote collaboration and encourage cooperation between employees at all levels of the organisation would seem an obvious way forward, but how easy is it to know how others feel if there is no platform for asking relevant questions or sharing information? Where more can be done to facilitate these, trust can be built more readily - a powerful motivator and source of reassurance in uncertain times. Insecurity over resources promotes competition between colleagues, so taking steps to keep all employees informed of change underlines the need not only for effective and regular communication, but also for attention to issues of well-being and fairness - in other words the psychological currency of the workplace. As we have seen in Chapter 7 by Richard Kwiatkowski, the example of Parliament in the Brexit period illustrated the difficulties of rivalry and hostility and the need to work together differently to achieve positive outcomes - things which appeared obvious to observers outside the House of Commons.

Fairness, hopefully, is hard to argue with as a concept. We should be able to expect it in society and therefore at work. However, attitudes which have resulted in discrimination towards citizens and communities in the UK - historically as well as in the present - are evident. The Windrush Scandal and the removal of guarantees from the Brexit Withdrawal Agreement to unite separated families are poignant examples. The absence of compassion from dealings with individuals who had previously been led to believe they had every right to remain, but were removed or barred from the UK has continued with the 'hostile' environment, itself attributed to taking root during Theresa May's period as Home Secretary. Examples of citizens who have in good faith devoted their working lives to the UK 
and then been subject to removal without warning point to the need to overhaul and independently oversee automatic enforcement of expulsion rules and processes. The human dimension needs restoring. There are direct implications for workplaces, where organisations are given responsibility for policing the employment status of employees. There is room for a more compassionate and practical approach. It is not surprising that the British Psychological Society is among a number of organisations calling for assessment of the psychological impact of policies pursued by government (BPS, 2020).

The chapter by Nikos Drosos and Alexander Antoniou (Chapter 8 ) highlights the impact of Brexit on higher education and in particular concerns facing students and staff from the EU, as well as funding opportunities for UK research. Disturbing examples have emerged where academic employees, originally from overseas who settled and have families in the UK, have been refused indefinite leave to remain by the Home Office, as they had spent time gathering data overseas as part of their UK-based university work! (The Guardian, 2020). Some cases have been overturned on appeal but this relies on individuals being wellpositioned to oppose legal rulings, during which time visas may expire and individuals' working rights and jobs suspended. A key factor with implementing government policies is the role played by those empowered to put them into practice - a common sense and compassionate approach is essential but can be overtaken by inflexible and over-zealous pursuit of targets.

Perhaps it is reassuring that pages $43-50$ of the Brexit Withdrawal Agreement (HM Government, 2019a) address employment status and make clear there should be no discrimination, 'on grounds of nationality as regards employment, remuneration and other conditions of work and employment' (p. 43). In theory at least, this would put fairness at the centre of post-Brexit legislation to underpin workplace equality for all working in the UK, whether an EU, non-EU or UK citizen. However, the Government approach to migration announced in February 2020 promoted differential treatment of those wishing to enter the UK based on skill levels, as defined by officials and the Migration Advisory Committee.

The Government's policy announced the replacement of free movement with a pointsbased migration system, with minimum pay thresholds which EU workers coming to the UK would generally need to exceed. The emphasis focuses on attracting highly skilled employees and the Government's stance appears unequivocal: 'We need to shift the focus of our economy away from a reliance on cheap labour from Europe and instead concentrate on investment in technology and automation. Employers will need to adjust'. Within weeks of publication of this document and as if to serve as a sobering reality check, flights bringing fruit pickers from Romania were landing in the UK to help harvest its crops during the Coronavirus lockdown and the Prime Minister was giving thanks to nurses from abroad for saving him from the virus. The Government had previously acknowledged that $70 \%$ of individuals who had entered the UK since 2004 from the European Economic Area would not be able to enter had they applied under the new system introduced after January 2021 (but those already here are entitled to apply to remain). These strategies provide clear challenges for organisations and workers. However, there is Government recognition of the need for flexibility - at least in the short term - in certain occupations, including within the 
National Health Service and agriculture. Entry routes for jobs defined as less-skilled would still be available for non-EU migrants, but the Government indicated its desire 'that employers move away from a reliance on the UK's immigration system as an alternative to investment in staff retention, productivity, and wider investment in technology and automation' (Home Office, 2020). However, the language of Government and its leaders needs to be careful to avoid inadvertently - or otherwise - inciting negative attitudes. Research findings confirm that this knock-on effect is real (Flores et al., 2018) and that its consequent impact on the well-being of EU migrants is also evidenced (Frost, 2020).

There is anecdotal evidence of organisations in less regulated areas whose leadership views Brexit as an opportunity to move away from equal treatment and this clearly demands vigilance as well as support for affected employees. Experimental research has also illustrated the potential for discrimination in recruitment processes against employees whose background is from outside the UK (Di Stasio and Heath, 2019). The Arbitration, Conciliation and Advisory Service (ACAS), which is sponsored by the Government's Department for Business, Energy and Industrial Strategy, is clearly important in providing to 'employees and employers free, impartial advice on workplace rights, rules and best practice' (ACAS, 2020).

The Brexit withdrawal document highlights that citizens already residing in the UK and EU 'will continue to be able to live and work in the EU and UK respectively - unless they leave for over five years' (Institute for Government, 2020). However, in order to guarantee these rights, EU citizens living in the UK will need to apply for 'settled status', which does raise the prospect of a final deadline for applications and the alarming threat of suspending rights to work of those who have not applied by then (Owen, 2020). This approach risks falling out of step with the political declaration signed by the UK and EU outlining the framework for future relations. This agrees it 'should be approached with high ambition [...] Above all, it should be a relationship that will work in the interests of citizens of the Union and the United Kingdom, now and in the future.' (HM Government, 2019b, p. 3). Care and reflection is required in the fulfilment of such ambitions, not least in light of the Coronavirus pandemic.

\section{SAFEGUARDS FOR THE FUTURE WORKPLACE}

As the earlier chapters by Alexander Antoniou and Nikos Drosos on Corporate Social Responsibility (Chapter 6) and Christian van Stolk on employee health and well-being (Chapter 5) point out, the UK also has much to be proud of in initiating and fostering broadranging workplace initiatives. Accordingly there are foundations for hope in the treatment of employees in workplace organisations, as long as these are not eroded in the coming years. The Health and Safety Executive (HSE) in the UK provides a cornerstone for good practice. However, publicity surrounding removal from the Withdrawal Agreement of guarantees to meet EU standards on workers' rights has stirred consternation. Nevertheless, the joint UK-EU Political Declaration does commit to maintaining 'social and employment standards at the current high levels provided by the existing common standards. In so doing, they should rely on appropriate and relevant [European] Union and international standards, 
and include appropriate mechanisms to ensure effective implementation domestically, enforcement and dispute settlement' (HM Government, 2019b, p. 15).

In terms of safeguarding the physical and psychological well-being of employees in the UK, these are currently underpinned by the Management Standards for stress (HSE, n.d.; first published in 2004) and guidance on improving mental well-being at work (National Institute for Health and Care Excellence (NICE), 2009; NICE, 2016). The HSE standards for addressing stress and poor mental health at work - which costs $£ 33-42$ billion annually in the UK (Deloitte, 2018) - are founded on seven aspects of the way in which we work. Decades of research have demonstrated the negative impact on workplaces of problems in these areas, which, 'if not properly managed, are associated with poor health and wellbeing, lower productivity and increased sickness absence' (HSE, n.d.). These areas are: demands (often referred to as workload), control and support, as well as contextual factors about the working environment, that is, change, relationships and roles (whether defined or indeed possible). Such a list is not finite and clearly the issues of job insecurity and the impact of modern working technologies are relevant to health, well-being and productivity outcomes for employees and organisations too (BPS, 2017).

NICE (2016) guidelines on improving wellbeing in the workplace emphasise the role of managers in organisations and flexible working arrangements, as well as the need to raise awareness of mental health at work, including monitoring and promoting positive interventions. Within considerations for managers, the concepts of a consultative approach, fairness and justice, valuing others and fostering positive behaviours are among the top priorities, underpinned by senior leadership support and appropriate training including coaching. These themes come as no surprise as they are replicated in topics which have emerged from this book. In other words a common sense approach to building a healthy organisation can be a reality whether times are stable or turbulent.

One challenge lies in the uptake of HSE and NICE guidelines and whether Brexit compounds this. Some research has shown that general awareness among organisations of HSE Management Standards for stress is relatively high (92\% compared with $77 \%$ for NICE guidelines), however, more detailed knowledge and implementation is much lower (Weinberg et al., 2018). Interestingly this is dependent on the backing of the senior management board in an organisation. Of 162 UK organisations of different sizes and sectors, 39\% had implemented HSE standards, but the uptake rose to $54 \%$ where 'health and wellbeing' was a regular board agenda item. A similar issue was noted with NICE guidance: $37 \%$ of participating organisations were familiar with its details but only $12 \%$ actually implemented them. Once again the backing of the senior management board was influential and in this sample, uptake of NICE guidelines was more frequent in the public and third sector than private sector organisations, and among larger rather than smaller organisations (Weinberg et al., 2018). The role of statutory bodies in promoting such important guidance is clear in ensuring uptake of positive approaches to the way we work. Just as importantly, the responsibility lies with employers and employees to use and act on available advice and avoid turning back from it. 
A 'Psychology of Survival' in the title of this book might suggest the future is less than rosy: a sentiment thrown into stark relief by the Coronavirus outbreak. However, this need not be the case. Taking stock of what has been achieved in workplace good practice and sound guidance for employees and organisations could provide some reassurance about what lies ahead. Nevertheless, the impact of political will in maintaining or eroding achievements is clearly important and as both the Brexit process and Coronavirus pandemic have shown, the role of citizens both inside and outside workplaces has driven the outcomes to date. It is hoped the voices of progressive employers and employees are heard in determining what works. If the aspiration is to be a global competitor - or perhaps as realistically to be an economic survivor of the Coronavirus pandemic - then the UK must continue to recognise the value of its multinational and multicultural workforce. There is no clearer reminder than the ultimate price paid by so many healthcare and logistics employees from diverse ethnic backgrounds and so many overseas nations, who gave their lives in saving others, working for the National Health Service and other organisations. The UK must also take action to further improve working conditions for all of its workforces, as without doing so it risks so much more than losing out to its competitors.

The proposal to spend large amounts of money on refitting the Big Ben bell on the UK Parliament at the Palace of Westminster - so the clock could ring out on the day the UK left the EU - suggested a triumphalism unlikely to bridge the social and political divides of the Brexit process. Whatever the symbolism of the famous clock tower chimes in sobering days as these, it would be tempting to say that 'only time will tell'. Yet it is possible to be certain of something. In whichever ways Brexit is manifest in advancing into the future, it is clear that human attitudes and behaviours as outlined by the contributors to this book will influence outcomes for all our workplaces.

\section{REFERENCES}

ACAS (2020). Making working life better for everyone in Britain. Accessed at: https://www.acas.org.uk/.

Boorman, S. (2009). NHS health and well-being review. Accessed at: http://webarchive.nationalarchives.gov.uk/20130107105354/http:/www.dh.gov.uk/en/Publ icationsandstatistics/Publications/PublicationsPolicyAndGuidance/DH_108799.

British Psychological Society (BPS) (2017). Psychology at work: Improving well-being and productivity in the workplace. Leicester: BPS. Accessed at: https://www.bps.org.uk/newsand-policy/psychology-work-improving-wellbeing-and-productivity-workplace.

British Psychological Society (BPS) (2020). Psychological government. Accessed at: https://www.bps.org.uk/blogs/chief-executive/psychological-government.

Compassion in Politics (n.d.). Accessed at: https://www.compassioninpolitics.com/.

Deloitte (2018). Mental health and well-being in employment. Independent report. Accessed at: www.deloitte.co.uk/MentalHealthReview. 
Department for Business, Energy and Industrial Strategy (2017). Good work: The Taylor review of modern working practices. Accessed at:

https://www.gov.uk/government/publications/good-work-the-taylor-review-of-modernworking-practices.

Di Stasio, V. and Heath, A. (2019). Are employers in Britain discriminating against ethnic minorities? Centre for Social Investigation, Nuffield College.

Edmans, A. (2008). Does the stock market fully value intangibles? Employee satisfaction and equity prices. Journal of Financial Economics, 101(3), 621-40.

Fahy, N., Hervey, T., Greer, S., Jarman, H., Stuckler, D., Galsworthy, M. and McKee, M. (2019). How will Brexit affect health services in the UK? An updated evaluation, The Lancet, 393, 949-58.

Financial Times (2019). Trade bodies appeal for regulatory alignment. Financial Times, 11 October. Accessed at: https://www.ft.com/content/a29b405e-ec41-11e9-a2403b065ef5fc55.

Flores, A.R., Hatzenbuehler, M.L. and Gates, G.J. (2018). Identifying psychological responses of stigmatized groups to referendums. Proceedings of the National Academy of Sciences of the United States of America, 115(15), 3816-21.

Frost, D.M. (2020). Hostile and harmful: Structural stigma and minority stress explain increased anxiety among migrants living in the United Kingdom after the Brexit Referendum. Journal of Consulting and Clinical Psychology, 88(1), 75-81.

HM Government (2019a). Agreement on the withdrawal of the United Kingdom of Great Britain and Northern Ireland from the European Union and the European Atomic Energy Community. Accessed at:

https://assets.publishing.service.gov.uk/government/uploads/system/uploads/attachment data/file/840655/Agreement_on_the_withdrawal_of_the_United_Kingdom_of_Great_Brita in_and_Northern_Ireland_from_the_European_Union_and_the_European_Atomic_Energy_ Community.pdf.

HM Government (2019b). Political declaration setting out the framework for the future relationship between the European Union and the United Kingdom. Accessed at: https://assets.publishing.service.gov.uk/government/uploads/system/uploads/attachment data/file/840656/Political_Declaration_setting_out_the_framework_for_the_future_relatio nship_between_the_European_Union_and_the_United_Kingdom.pdf.

Home Office (2020). The UK's points-based immigration system: Policy statement, 19 February. Accessed at: https://www.gov.uk/government/publications/the-uks-points-basedimmigration-system-policy-statement/the-uks-points-based-immigration-system-policystatement.

HSE (2004). What are the management standards? Health and Safety Executive. Accessed at: http://www.hse.gov.uk/stress/standards/. 
Institute for Government (2020). Brexit deal: The withdrawal agreement. Accessed at: https://www.instituteforgovernment.org.uk/explainers/brexit-deal-withdrawal-agreement.

NICE (2009). Public health guidance 22: Promoting mental wellbeing through productive and healthy working conditions: Guidance for employers. National Institute for Health and Care Excellence. Accessed at: https://www.nice.org.uk/guidance/ph22/resources/advice-forsmall-and-mediumsized-businesses-pdf-67277917.

NICE (2016). Guideline [NG13]: Workplace health: Management practices. National Institute for Health and Care Excellence. Accessed at: https://www.nice.org.uk/guidance/ng13.

Owen, J. (2020). Five causes of concern about citizens' rights after Brexit - and what the government should do. Institute for Government. Accessed at:

https://www.instituteforgovernment.org.uk/blog/five-causes-concern-about-citizens-rightsafter-brexit.

Personnel Today (2019). Post-Brexit judges' powers plan prompts workers' rights fears. Personnel Today. Accessed at: https://www.personneltoday.com/hr/post-brexit-judgespowers-plan-prompts-workers-rights-fears/.

The Guardian (2020). Home Office penalises academics for fieldwork outside of UK. The Guardian, 25 February.

Weinberg, A., Hudson, J., Pearson, A. and Chowdhury, S.B. (2018). Organisational uptake of NICE guidance in promoting employees' psychological health. Occupational Medicine, 69(1), 47-53.

YouGov (2016). How Britain voted at the EU Referendum. Accessed at: https://yougov.co.uk/topics/politics/articles-reports/2016/06/27/how-britain-voted.

YouGov (2019). How Britain voted in the 2019 General Election. Accessed at: https://yougov.co.uk/topics/politics/articles-reports/2019/12/17/how-britain-voted-2019general-election.

YouGov (2020). Four in ten SMEs not ready for Brexit. Accessed at: https://yougov.co.uk/topics/finance/articles-reports/2020/01/29/most-smes-feel-readybrexit-also-say-government-ha. 